\title{
The role of gender in the South European immigration model
}

\author{
Russell King \\ Elisabetta Zontini
}

University of Sussex. School of European Studies

Falmer, Brighton, BN1 9QN

R.King@sussex.ac.uk

E.Zontini@sussex.ac.uk

\begin{abstract}
The aim of this article is to contextualise female migration into Southern Europe within the specificities of the Southern European model of immigration. Very different from the intraEuropean labour migrations of the 1950s and 1960s, when the Southern European countries were themselves suppliers of labour migrants, this new South European immigration model comprises a number of key features such as heterogeneity of migrant source countries (especially true for Italy and Spain), the dynamic role of the informal economy, a heavy concentration of immigrant employment in the tertiary sector, and the highly segmented structure of labour demand into which different ethnic and gender groups find niche opportunities. Particularly relevant for the role of immigrant women in this setting are the social changes affecting the position of South European women both in the labour market and in the home and family contexts. Although the article is mainly concerned with the above theoretical issues, reference will also be made to a sample of empirical studies on immigrant women, especially in Italy.
\end{abstract}

Key words: Southern Europe, informal economy, tertiary sector, labour segmentation, gender and ethnic groups.

Resumen. El rol del género en el modelo de inmigración en la Europa del Sur

El objetivo de este artículo es contextualizar la inmigración femenina en la Europa del sur dentro de las especificidades del modelo de inmigración de la Europa del sur. Un modelo muy distinto del de las migraciones europeas de trabajo de los años cincuenta y sesenta, cuando los países de la Europa del sur ofrecían mano de trabajo migrante. Este nuevo modelo de inmigración en la Europa del sur comprende un número de características clave como son la heterogeneidad de los países de origen (especialmente para el caso italiano y español), un dinámico rol de la economía informal, una gran concentración de los inmigrantes en el sector terciario y una estructura de la demanda laboral muy segmentada, en la que los diferentes grupos étnicos y de género hallan "oportunidades nicho». En este contexto es especialmente relevante para el rol de las mujeres inmigrantes los cambios sociales que afectan a la posición de las mujeres de la Europa del sur, tanto en el mercado como en el hogar. A pesar de que el artículo se centre principalmente en aspectos teóricos, se hace también referencia a estudios empíricos sobre mujeres inmigrantes, especialmente en Italia.

Palabras clave: Europa del sur, economía informal, sector terciario, segmentación del trabajo, grupos de género, grupos étnicos. 

Summary
1. Introduction
4. Sectors of female employment
2. Reasons for immigration into Southern Europe
3. The economics and sociology
5. Conclusions
References

of labour market segmentation

\section{Introduction}

For at least the last hundred years, the countries of Southern Europe ${ }^{1}$ have had an intense experience of migration. The region's migratory history has seen, first, a massive permanent emigration overseas, mainly to the Americas, in the late nineteenth and early twentieth centuries; then a more temporary form of labour migration to the industrialised countries of Northern Europe in the period between the end of the Second World War and the first oil crisis; next a wave of return migration driven partly by the changed economic conditions of the 1970s and early 1980s; and finally a recent phase of immigration, mainly from the countries of the developing world and, after 1990, from Eastern Europe. This historical sequence is undoubtedly a crude approximation and overlooks several important deviations from the generalisations: for instance the fact that there were some returns from the so-called «permanent settlement» emigrations overseas, or the even more important tendency for the so-called «temporary labour migrations» of the postwar decades to rapidly evolve into permanent settlement of Southern European ethnic communities in Northern European countries. Moreover, this is a typology only of external migration: equally massive internal redistributions of population have taken place, especially in the first three decades of the postwar period. These too have had a common pattern across the whole of Southern Europe: from rural regions to the main towns and metropolitan areas; from inland areas to the coast; from marginal upland and mountain districts to more fertile and urbanised plains; and from poor regions with low incomes and high rates of unemployment to richer regions undergoing rapid industrial and urban growth.

The various national and international comparative literatures on these multiple migratory phenomena are enormous: so large in fact that there is no point, given the main purpose of this article, to cite even a sample of refer-

1. For the purposes of this paper the countries of Southern Europe are taken to be Spain, Portugal, Italy and Greece. Malta, Cyprus and, to some extent, Slovenia have had similar migration histories but almost no information is available on recent immigration into these small countries, except that it exists on a significant scale. There is some evidence of recent immigration to Turkey but the scale and nature of this migration (much of which is transit migration) as well as the nature of economic and social change in Turkey, make this country still very different from the southern EU states, and more akin to North African countries like Tunisia or Morocco. 
ences here. What is more important, in terms of the background context for the present paper, is the fact that these literatures, vast as they are, almost always constructed migration as a male project. Despite the fact that the detailed migration statistics show otherwise, the accounts explicitly or implicitly assume that it was predominately men who crossed the ocean, migrated to work in the factories of Western Europe, or left the farms of Southern Italy or the hills of Greece to work in the industries and service sectors of Milan, Rome or Athens. This "gender-blindness» has been one of the major failings of the otherwise rich and dynamic interdisciplinary field of Southern European migration studies.

Only over the past 10-15 years have some correctives been applied to the male bias of migration research. Following the development of feminist approaches to social science in the 1970s and early 1980s, important and powerful general statements were made about the female dimension in European international migration by Phizacklea (1983) and Morokvasic (1984), whilst some detailed sociological and anthropological case-studies of Southern European migrant women also started to appear at the same time (see, for instance, Brettell, 1982; Cornelisen, 1976; Douglass, 1976; Panayotakopoulou, 1981). Meanwhile historians and others reappraised past migrations, re-mapping the overlooked role of women onto the hitherto male-dominated historical record (Schwartz Seller, 1981; Simon and Brettell, 1986).

The migratory role of women has become, if anything, even more important in the globalised economy of the late twentieth century. Castles and Miller (1993: 8-9) identify the feminisation of international migration as one of the key trends of the new "age of migration", a point echoed in many other glob$\mathrm{al}$ and regional surveys of recent, current and future international migration (e.g Hugo, 1998: 31-35). Whilst these trends reflect partly the growing independence of women and the demand for female labour in the restructured global economy with its emphasis on tertiary sector over industrial sector employment, by no means always does this imply the empowerment of women as independent actors in the migration process ${ }^{2}$. Far from it, in fact. Very often the increasing participation of women in international migration simply reflects their growing "marketability» on the global labour market and their cynical manipulation by a variety of essentially patriarchal structures: household and family structures in the countries of origin; unscrupulous trafficking agents in the act of migration itself; and patriarchal social and employment practices in the regions of destination, like Southern Europe.

Having set out this historical and intellectual context, the main purpose of this paper is to interpret the female dimension within the current Southern European immigration scene. This is done at a fairly high level of abstraction and generalisation, reflecting our belief that there are common patterns and

2. Two types of female migration can be distinguished: dependent migration, often linked to family reunion; and autonomous migration, often linked to a personal project or family strategy. Individual situations are frequently more complex than this, of course. 
processes shared by Southern European countries as regards their recent social, economic and demographic evolution. Working towards the idea of a specific Southern European «model» of immigration, we will attempt to locate the gender dimension within this model, paying particular attention to the phenomenon of labour market segmentation, to the sectors of employment where migrant women are now employed in large numbers in Southern Europe, and to the geography of the migration flows. In fact, we maintain that the sharp gendering of migration streams and of employment types is one of the key features of this Southern European immigration model. Although we do not offer a complete literature review, we will deploy a sample of case-studies and statistical data to put some empirical flesh on the theoretical bones of our main analysis.

\section{Reasons for immigration into Southern Europe}

Some of the reasons for the "turnaround" in the external migration status of Southern Europe from a region of emigration until the 1970s to one of immigration in the 1980s and 1990s are well-known and have been discussed in a number of recent studies (King and Konjhodzic, 1995; King and Rybaczuk, 1993; King et al., 1997; Simon, 1987; Werth and Körner, 1991). They do not need an extensive replay here, but need to be briefly summarised since they are of relevance in our attempt to compose a South European model of immigration in the next section of the paper.

Three groups of factors can be identified. The first set can be grouped under the heading of geography. These include the position of the southern EU countries on the Mediterranean flank of Europe, facing the access routes of immigrants coming both from nearby countries (Morocco, Tunisia, Egypt, Albania) and from much further away; the very long coastline of Southern Europe with its many beaches and islands, impossible to patrol effectively without a major military exercise; the mountainous borders of north-east Italy (with Slovenia) and north-west Greece (with Albania) which can be crossed by migrants using remote paths; and the fact that Southern Europe (especially Spain and Italy) had already functioned in earlier decades as transit countries for North African migrants routing overland to France and the Benelux countries. Hence in the strategic language of migration control, Southern Europe has come to be known as the "soft underbelly" of Fortress Europe, the frontier where the external border of Schengen seems most weak.

Second, there are economic factors. The first of these overlaps with the previous set: the economic geography of Southern Europe in which several of the main sectors of the economy - tourism, shipping, fishing - involve an open set of linkages with the outside world which, again, facilitates the arrival of immigrants. Otherwise, the main economic factor is the spectacular development and modernisation of the Southern European economies between the 1960s and the 1980s; this provided the broad structural context for their parallel transformation from emigration to immigration countries. 
Cartographically this transformation can be mapped as a fundamental shift south of the "migration frontier" - the boundary between countries of emigration and those of immigration - from its position running along the Pyreneean and Alpine watersheds in the 1960s to a new location running through the southern margins of the Mediterranean Basin in the 1980s (see King, 1998: 126-127). This is the notion of the Mediterranean as Europe's «Rio Grande» (Montanari and Cortese, 1993: 213-218) — the liquid divide between the rich north shore and the poor southern shore. Across this divide two economic systems and demographic regimes confront each other, leading to unquenchable pressures for northwards migration. The Mexican «wetbacks» who swam the Rio Grande to reach their El Dorado in the north have their Mediterranean equivalents across the Strait of Gibraltar and the channel between Albania and Corfu.

Third, there are socio-demographic factors. The Mediterranean Rio Grande separates two population regions that constitute the sharpest demographic gradient in the world. On the north side are countries which have experienced dramatic fertility collapse, in the case of Spain and Italy down to an average of 1.2 children per woman in the mid-1990s. Total fertility rates are three to five times higher in the southern shore countries. Whilst it is true that fertility is falling fast in countries like Morocco, Tunisia and Turkey, population structures remain dominated by young cohorts who have a poor economic future in their home countries (King, 1997).

This simple listing and categorisation of reasons for immigration tells us nothing about the relative importance of each factor nor about how they have interacted together to "produce» the immigrations that have been such an important part of Southern European societies and economies in the past 15-20 years ${ }^{3}$. It also needs to be appreciated that the factor combinations have varied over time and with respect to the several sending states and the four receiving countries. Above all, we believe that the interaction between economic, labour market and sociological factors is the key to understanding the nature of recent immi-

3. Given the important flows of undocumented migrants, we cannot be exact about the quantitative scale of this impact. Simon (1987: 284) estimated 2 million immigrants and Werth and Körner (1991) increased the estimate of the growing stock of immigrants to 2.7-3.0 million for their survey date of 1989. Both of these sources were before the opening up of significant «east-to-south» migration currents as a result of the removal of the Iron Curtain. A more recent estimate by Baldwin-Edwards (1997), based on a compilation of national records and estimates for the early-mid 1990s, yields 2.5 million, but our view is that Baldwin-Edwards uses low estimates for Spain and Portugal, as against more realistic estimates for Greece and Italy. Periodic regularisations in recent years in Italy, Spain and Portugal have shed a little more light on this vexed issue of numbers. Legal immigrants registered on 31 December 1996 were 1,095,622 for Italy, 538,984 for Spain, and 172,912 for Portugal. The enigma is Greece, where Baldwin-Edwards estimates 140,000 legal and 500,000 illegal immigrants; here there is a regularisation programme currently in progress (1998). If we accept Baldwin-Edwards' figures for Greece and add a (very) notional $30 \%$ to the Italian, Spanish and Portuguese figures to cover illegal immigrants in those three countries, we arrive at a total of 3 million. 
gration into Southern Europe, including its sharply differentiated gender dimensions. This is the task of the next section of the paper.

\section{The economics and sociology of labour market segmentation}

The specification of a distinct South European pattern of immigration must be embedded within the specific model of South European capitalistic development, with its associated societal characteristics. Mingione (1995) has identified a South European variant of European capitalism whose essential features are as follows. First, South European countries are «late developers». This means that, on the whole, they do not have a legacy of out-dated nineteenthcentury industry and other obsolete economic structures, although exceptions to this can be found in those few regions (Basque Country, Catalonia, the Industrial Triangle of north-western Italy) where heavy industry was established by the early decades of the present century.

Second, Southern Europe's path to modernisation has proceeded largely through a direct shift from a rural, agricultural economy (and society) to an urban, service-based economic and social structure. Missing out both the nineteenth-century industrial revolution and (again with the exception of some regions like Catalonia, Madrid, Rome and parts of Northern Italy) the mass industrial expansion of the postwar Fordist era that was so important in Northern European countries (and which drew large labour migration flows from Southern Europe in the 1950s and 1960s), Southern Europe's leading economic sectors have been specialised agriculture, construction, tourism and other services. Table 1 demonstrates that, during 1980-90, the decade when immigration flows into Southern Europe started to become large in scale, both agriculture and industry lost employment to the fast-growing service sector.

Third, these sectoral employment changes have been sharply differentiated with respect to gender (table 2). Most of the labour losses in agriculture

Table 1. Southern Europe: sectoral employment trends. 1980-90.

\begin{tabular}{|c|c|c|c|c|c|}
\hline & \multicolumn{3}{|c|}{ Percentage of active population in: } & \multirow{2}{*}{$\begin{array}{l}\text { Share of active population } \\
\text { who are self-employed (\%) }\end{array}$} \\
\hline & & Agriculture & Industry & Services & \\
\hline \multirow[t]{2}{*}{ Italy } & 1980 & 14,3 & 37,9 & 47,8 & 28,6 \\
\hline & 1990 & 9,0 & 32,4 & 58,6 & 28,8 \\
\hline \multirow[t]{2}{*}{ Greece } & 1980 & 30,3 & 30,2 & 39,5 & 50,3 \\
\hline & 1990 & 24,5 & 27,4 & 48,2 & 48,6 \\
\hline \multirow[t]{2}{*}{ Spain } & 1980 & 19,3 & 36,1 & 44,6 & 28,5 \\
\hline & 1990 & 11,8 & 33,4 & 54,8 & 26,4 \\
\hline \multirow[t]{2}{*}{ Portugal } & 1980 & 27,3 & 36,6 & 36,1 & 32,4 \\
\hline & 1990 & 17,8 & 34,8 & 47,4 & 29,7 \\
\hline
\end{tabular}

Source: OECD (1991). 
Table 2. Southern Europe: active population by sex 1980-90.

\begin{tabular}{|c|c|c|c|c|c|c|c|}
\hline & & \multicolumn{3}{|c|}{ Active Population ('000) } & \multicolumn{3}{|c|}{ Activity Rate (\%) } \\
\hline & & Total & Male & Female & Total & Male & Female \\
\hline \multirow[t]{2}{*}{ Italy } & 1980 & 22.553 & 15.038 & 7.515 & 60,8 & 82,8 & 39,6 \\
\hline & 1990 & 24.293 & 15.347 & 8.946 & 61,1 & 78,1 & 44,5 \\
\hline \multirow[t]{2}{*}{ Greece } & 1980 & 3.451 & 2.414 & 1.037 & 55,9 & 79,6 & 33,0 \\
\hline & 1990 & 3.967 & 2.500 & 1.467 & 60,9 & 75,8 & 43,5 \\
\hline \multirow[t]{2}{*}{ Spain } & 1980 & 13.497 & 9.661 & 3.837 & 57,1 & 82,3 & 32,2 \\
\hline & 1990 & 15.333 & 9.998 & 5.335 & 58,8 & 76,8 & 40,9 \\
\hline \multirow[t]{2}{*}{ Portugal } & 1980 & 4.361 & 2.628 & 1.773 & 70,5 & 87,7 & 54,3 \\
\hline & 1990 & 4.756 & 2.715 & 2.041 & 73,1 & 85,6 & 61,3 \\
\hline
\end{tabular}

Note: The activity rate is calculated by percentage of the population aged 14-65 who are at work or actively seeking work.

Source: OECD (1991).

and industry have been of unqualified male workers, or of male workers possessing artisan skills that are no longer in demand in the technology-dominated era. Most of the gains, on the other hand, have been in «female» jobs in the service sector. These trends have continued in the 1990s. Female participation rates in the labour market are continuing to increase since, from the demand side, job creation tends to be in various branches of the tertiary sector (from banking and insurance to catering and tourism) where females can most easily find work, both as highly qualified personnel and as less skilled casual workers ${ }^{4}$.

Fourth, all Southern European economies incorporate an important and dynamic informal sector which relies not only on the conventional mechanisms of tax evasion and social security avoidance, but also on a range of flexible labour market practices including subcontracting, moonlighting and the diffusion of short-term, seasonal and part-time work regimes ${ }^{5}$. Such labour market practices respond well to the seasonal pattern of many of the key productive sectors of the Southern European economy (farming, fishing, con-

4. The trend to the casualisation of the labour market is a general European phenomenon. Most new jobs created in the EU in the first half of the 1990 s were part-time. Whilst temporary jobs account for around $12 \%$ of total employment in the EU, over $50 \%$ of the umemployed who found jobs in 1995 took up temporary positions (European Commission, 1996: 17).

5. The informal sector, also referred to as the black economy, the parallel economy, the submerged economy etc. (though these terms are not necessarily synonymous), accounts for a significant proportion of GDP in the Southern European economies — shares estimated at around 30\% in Greece and 15-25\% in Spain, Portugal and Italy (where it is much higher in the Mezzogiorno). For a review of the varieties of informal sector activity and employment in Southern Europe see King and Konjhodzic (1995: 27-34); also Williams and Winderbank (1995). 
struction, tourism) and to the underlying organisational structure of these activities, fragmented into a myriad of small firms and individual employers (Iosifides and King, 1996). Table 1 (final column) shows the extremely high incidence of self-employment in the Southern European countries - $25-30 \%$ of total employment in Italy, Spain and Portugal, nearly 50\% in Greece.

The role of the informal economy has been absolutely fundamental in conditioning the types and outcomes of immigration into Southern Europe, although it is curious that this link has only very recently started to be explored (Baganha, 1998; Droukas, 1998; Iosifides and King, 1996; King and Konjhodzic, 1995; Reyneri, 1998; Solé et al., 1998) No longer regarded as a vestige of backwardness associated with underdeveloped urban economies in the Third World, the informal sector in Southern Europe is dynamic and probably expanding: above all it is a flexible and pragmatic response to heavy state regulation and to global processes of restructuring and competition connected to the international division of labour. It was well established in Southern Europe before the recent immigration, and is widespread amongst virtually all sectors of the population and across most sectors of economic activity. In short, it probably touches the everyday life of most households in most parts of the region. Hence it is not correct to target immigrants as the "cause» of the existence of undocumented economic activities. On the other hand, immigrants have interacted with the black economy in a very dynamic way, causing it to expand and reshape itself in many new directions. For many years, until the regularisations of the mid-1980s and the 1990s, the underground economy was the first and only chance immigrants had of obtaining any kind of work; in Greece this remains the case for most immigrants. Moreover the boundaries between the formal and the informal are never sharply drawn and are constantly being redefined, both at the institutional/legal level and at the level of individual economic actors - employers, employees, households, immigrants, etc. A regularisation campaign will decrease the population of undocumented immigrants, but possession of a residence and work permit does not necessarily mean participation in the formal economy.

In sum, Southern Europe since the 1970s has provided a continuing vindication of Piore's (1979) thesis that immigrant labour is fundamental to the ongoing development of capitalism, even in its post-Fordist phase, permitting and responding to the structuring of a segmented labour market. By the latter term we mean not only the existence of a simple dual labour market as posited by Piore, but also the elaboration of highly fractioned submarkets of labour which are differentiated territorially, by economic sector, by type of work and by gender. Competition between these submarkets is limited because of the unwillingness now of indigenous labour to perform jobs that were once in short supply compared to demand - in agriculture, construction, tourism and in low-grade personal and domestic services. The existence of different wage levels for the indigenous and immigrant labour markets, especially if the immigrants are illegal, only serves to cement the barriers between different segments of employment. 
Two sociological changes need to be added to our analysis to complete the portrayal of the South European economic and labour market model and its gendered dimension. The first is the rapidly expanding number of years spent in full-time education. Only a small, residual share of young persons now leave school at the minimum age: most stay on to complete secondary schooling and an increasing fraction, at least a third, enrol at university. Parents support their children in education to boost their job and life chances, to hope that they find a higher-status marriage partner, and to improve family prestige. Because most young persons continue to live at home when at university (in contrast to some North European countries), parents are more easily able to subsidise their children's lives, even until their late 20 s or later. This exaltation of education as a route to enhancing personal and family status naturally reduces the supply of native labour for menial and unskilled jobs, thereby opening the market for low-status employment to foreign workers. Even the threat (and reality) of unemployment does not push highly-educated young men and women who have been «trained» for professional and office jobs to apply for lowergrade employment: they prefer to remain out of work, semi-employed or as perpetual students, supported by their indulgent parents and by a welfare system which, although undoubtedly still deficient in many respects, has made great strides since the 1950s and 1960s when it was almost non-existent.

The second key social change which has directly impacted on immigrant work opportunities is Southern Europe's imperfect transition to gender equality. Whilst, since the 1970s, young women have increasingly had access to education and careers, rejecting their traditionally allocated role of «non-working» wife and mother, this equalisation of opportunity (which in reality is far from fully achieved since in most careers and professions it is men who hold nearly all the powerful positions) has not been matched by equality within the domestic sphere. In other words career women are expected by their husbands and partners to fulfil most of the domestic roles of cooking, cleaning, child care and caring for elderly parents. Given the declining kinship support for childminding due to the break-up of the traditional Southern European extended family, and given the lack of state nursery facilities, women and households have tended to resort to employing domestic cleaners, baby-sitters, care-helpers etc., who are often immigrant women. This example provides a lead-in to the next part of the article, which is a more systematic examination of the types of jobs undertaken by immigrant women in Southern Europe.

\section{Sectors of female employment}

In contrast to the earlier «migrations of Fordism» when the incorporation of foreign labour was highly regulated and consisted, at least initially, largely of male workers recruited into the formal sector and into industry (though the quantity and significance of female labour migration were always overlooked), the insertion of immigrants into employment in Southern Europe has been into an economic structure dominated by tertiary activities, by a vibrant informal sector, 
and by labour market niches which have come to have specific ethnic and gender characteristics (Pugliese, 1993). And unlike the situation in the past, when Southern Europeans were the migrants, the migrants of the "new wave» cannot benefit from a prosperous industrial economy that was prepared to offer at least some guarantees of employment security and social welfare. Rather, immigrants who have recently arrived in Southern Europe have had to cope with a more complex social and economic situation where, it seems, the key problem is to define one's own occupational identity within a segmented labour market (Mingione and Quassoli, 1999). An extra layer of complexity is added by the diversity of source countries and by the marked gender asymmetry of many of the national flows. Some flows have started and remain overwhelmingly male - this is particularly true for some West African flows. Other flows are started by males but then evolve into family migration; there is evidence that this is starting to happen for Moroccans in Spain and Italy. However, in other cases females migrate first, as in the case of migrants from South America and the Philippines, and then either start networks that subsequently involve male migrants (such as the Filipino case) or remain as overwhelmingly female communities, as with Cape Verdeans in Italy. The explanations for this differential evolution of gender profiles are inevitably complex, and have to be sought in the nature of the sending societies, the selectivity of the migration process regarding class, custom and educational background, the opportunities for work in the destination countries, the legal/irregular status of different national groups in the host society, as well as other aspects of transnational migration dynamics.

Table 3 presents some specific data on the sex composition of the main migrant groups in Italy according to residence permit data for 31 December 1996. This shows that, although females are in a slight minority overall $(44.7 \%$ of the 1,095,622 registered foreigners), most migrant communities have a female majority. This paradox is explained by two statistical facts: males tend to dominate the largest communities, and the degree of male dominance tends to be greater than the female majority percentage. Male-dominated communities tend to be from North or West Africa (Morocco, Tunisia, Egypt, Senegal, Ghana) or from the Balkans (Albania, Serbia, Macedonia), plus some Asian countries (Sri Lanka, India, Iran, Turkey). Most of these countries are Moslem; none is Roman Catholic ${ }^{6}$. Female-dominated countries have the following characteristics: the main geographical areas are Europe, Latin America and the former Italian colonies (Somalia, Ethiopia, Eritrea), plus the United States and a small number of other significant countries (Philippines, Thailand, Cape Verde); a majority are Catholic countries. It should be pointed out that most of the migrants (female and male) from Western Europe and the USA are in Italy for professional reasons, marriage or retirement; hence they are not the conventional economic migrants that are the main subject of this paper.

6. We make this remark purely as an observation; we do not imply any cultural or religious determinism. 
Table 3. Italy: Major immigrant communities by sex, 31 December 1996.

\begin{tabular}{|c|c|c|c|c|c|}
\hline Female majority $(>60 \%)$ & no. & $\% \mathrm{~F}$ & Male majority $(<40 \%)$ & no. & $\% \mathrm{~F}$ \\
\hline Philippines & 57.071 & 67,3 & Morocco & 119.481 & 20,0 \\
\hline USA & 54.652 & 64,8 & Albania & 63.937 & 27,7 \\
\hline Poland & 27.375 & 66,1 & Tunisia & 44.821 & 16,2 \\
\hline France & 25.585 & 61,2 & Serbia & 44.259 & 36,2 \\
\hline Peru & 21.738 & 70,0 & Senegal & 31.870 & 5,2 \\
\hline Brazil & 19.887 & 70,8 & Sri Lanka & 24.920 & 38,7 \\
\hline Spain & 16.842 & 67,5 & Egypt & 23.785 & 17,7 \\
\hline Russia & 11.367 & 71,0 & India & 19.417 & 38,0 \\
\hline Somalia & 11.235 & 66,3 & Macedonia & 16.419 & 17,2 \\
\hline Dominican Republic & 10.384 & 85,1 & Ghana & 16.379 & 34,6 \\
\hline Colombia & 9.154 & 74,1 & Iran & 6.910 & 36,4 \\
\hline Austria & 7.865 & 64,7 & Ivory Coast & 5.086 & 35,6 \\
\hline Ethiopia & 7.321 & 71,5 & Turkey & 4.338 & 39,7 \\
\hline Bulgaria & 5.632 & 62,5 & & & \\
\hline Hungary & 5.239 & 69,3 & & & \\
\hline Portugal & 4.898 & 60,0 & Mixed (40-60\%\%) & no. & $\% \mathrm{~F}$ \\
\hline Cape Verde & 4.592 & 85,2 & Germany & 36.515 & 58,6 \\
\hline Ecuador & 4.405 & 71,1 & Romania & 31.673 & 55,2 \\
\hline Cuba & 3.466 & 77,1 & China & 29.073 & 43,0 \\
\hline Sweden & 3.423 & 68,2 & UK & 24.779 & 57,9 \\
\hline El Salvador & 2.853 & 74,9 & Croatia & 18.865 & 44,5 \\
\hline Thailand & 2.573 & 86,4 & Switzerland & 17.923 & 56,1 \\
\hline \multirow[t]{4}{*}{ Eritrea } & 2.033 & 81,6 & Greece & 13.688 & 41,4 \\
\hline & & & Nigeria & 11.229 & 51,7 \\
\hline & & & Bosnia & 11.068 & 44,3 \\
\hline & & & Argentina & 8.383 & 55,0 \\
\hline
\end{tabular}

Source: Caritas di Roma (1997:102).

Regarding the main sectors of immigrant employment in Southern Europe, three are almost exclusively male: agriculture, construction and street-hawking. Different nationalities dominate these various activities in different destination countries: for example Albanians in Greek agriculture ${ }^{7}$, Senegalese street-hawkers in Italy, and Cape Verdeans and Angolans in construction in

7. Although Lazaridis and Romaniszyn (1998) note that some Albanian women are employed in farming as seasonal workers. 
Portugal. Two labour market niches are the almost exclusive preserve of immigrant women: domestic service and the sex trade. Finally there are other subsectors of the service sector, such as hotels and catering, which have been attractive both to immigrant women and immigrant men. The rest of this section of the paper concentrates on these female employment niches.

Domestic service is quantitatively the most important sector of immigrant female employment, taken across the four countries as a whole. In some senses domestic work blends into a broader categorisation of the role of immigrant women in the care sector. In Southern Europe a large amount of socially useful (indeed necessary) work such as childcare, nursery education, invalid care and care of the elderly is simply not done, either because the state budget does not prioritise such welfare, or because private households cannot afford to pay the market wages that would be demanded by indigenous workers working in the private sector. Employment of immigrant women from poor countries is an obvious solution. As a Somalian woman interviewed by Chell put it, «letting us enter Italy is a very clever move on the part of the Italians because they are freeing their own workforce so they can be more productive somewhere else» (Chell, 1997: 78).

As an immigrant employment specialism, domestic service has relatively early origins in Southern Europe, dating back to the hiring of Filipino and Cape Verdean maids in Italy in the 1960s and 1970s. Even before that there was a well-established tradition, especially in Italy and Spain, of the internal migration of domestic servants - young girls from poor, rural backgrounds who went to the big cities to work as maids for rich families. This earlier gendered migration, with its heavy emphasis on the domestic sphere and family solidarity, was strongly supported by the Catholic trade union movement (Andall, 1998). To some extent, then, the immigration of foreign domestic workers can be considered a replacement and development of this earlier internal migration, the supply of local girls willing to do this type of work tending to drop away after the 1960s. Another element of continuity was provided by the sponsoring role of the Catholic Church in channelling female migration flows from the Catholic countries specifically for work in the domestic sector - the classic «female» occupational sector in Catholic ideology (Andall, 1998). Filipinos remain the leading nationality involved in this sector in Spain, Italy and Greece but a range of other nationalities have also been incorporated in this sector: women from Somalia and Eritrea (ex-colonies of Italy) in Italy; women from a variety of Latin American countries (Peru, Colombia, El Salvador, Dominican Republic); Moroccan women in Spain; and, more recently, women from Eastern Europe (Droukas, 1998; Escrivá, 1997; Reyneri, 1998; Solé et al., 1998). While some of this migration is legal, with employees arriving with work permits as a result of specific recruitment quotas, there is also a great deal of clandestinity involved, especially when women change (or are forced to change) away from their original employer.

Most of the domestic and care workers are concentrated in major urban areas, where are also found the main concentrations of wealthy and middle- 
class professional households. Recently the fashion to employ a foreign domestic worker has become more widespread amongst lower-middle-class households, linked to the increasing propensity of married women to enter the labour market, and to the highly racialised notion of the possession of an "exotic maid" as a status symbol (Campani, 1999). This point deserves further analysis. The use of immigrant maids by women and households in the «richer world» of Southern Europe questions deeply the relationships between gender, race and class; and between developed and underdeveloped countries. According to Campani (1999) the mentality which prefers the archaic servant-master relation with the maid can be seen as the survival of old attitudes and habits (widespread in the Italian colonies, for example, where an African maid was also expected to provide sexual services); but it is also, perhaps, the product of an over-rapid modernisation which has occurred without the full interiorisation of the values of what might be termed the social-democratic model of the industrial or post-industrial society. As Campani points out, it is not by chance that in Sweden or Denmark, live-in domestic maids have practically disappeared; whereas the Southern European new bourgeoisie, recently arrived to high living-standards, considers the maid as a symbol of prestige.

As indicated above, most domestics live with the families they work for, but there is an increasing tendency to «live-out» and work on the basis of weekly or hourly pay, perhaps for several employers. This latter subgroup also includes some males, especially in Italy where Filipinos, Bangladeshis and Sri Lankans are perceived, in another heavy dose of racial stereotyping, as docile, hard-working and non-threatening. In Barcelona female domestic helpers from the Philippines tend to «live-in», Moroccan domestics «live-out» (Solé et al., 1998: 338). Although domestic workers are mainly located in cities, their geographical dispersion in individual households makes it difficult for researchers or social workers to observe their working conditions or levels of mistreatment, which may include sexual harassment. Compared to many other types of employment open to immigrant women (and men), domestic work tends to be quite well paid and have an element of security. However the work itself - cooking, cleaning, child-minding, care of elderly persons, etc. - may involve long hours and be little more than drudgery, whilst the relationship with the employer may be one of almost pure servility — «workers night and day» (De Filippo, 1994).

The second specialised sector of employment for immigrant women in Southern Europe is the sex trade, and more specifically prostitution. Quantitatively this sector is far less important than the migration of domestic workers, although there is an extreme lack of data on migrant sex workers, for fairly obvious reasons. What follows is a series of summary points from the recent work of Campani (1999) on foreign prostitutes in Italy. This work, which is still ongoing, is based on interviews with prostitutes and ex-prostitutes of various nationalities, as well as with other «expert witnesses»—social workers, police officers, journalists, etc. Campani and her research team esti- 
mate that there are between 18,800 and 25,100 foreign prostitutes and sextrade workers in Italy: the wide range of estimates derives partly from the sensitivity of the phenomenon and its shadow-economy nature, its high degree of seasonality and the fact that the persons involved are highly mobile geographically. A significant proportion have been subject to trafficking. The main geographical distribution reflects the concentration of the client population in the major cities and provincial capitals, together with a more seasonal market in tourist resorts. Two main nationalities dominate the prostitution trade, Nigerians and Albanians, but there are two further clusters of nationalities involved, Latin Americans and other East Europeans. These different nationalities arrived in Italy in a sequence of waves over the past ten years. For the Nigerians and Albanians the earlier arrivals were from the main towns (Lagos, Benin City, Tirana, Durres, Vlore) and had quite good levels of education. Later arrivals were from rural areas and had lower educational standards; many had been tricked by unscrupulous agents and «friends» who promised them careers as dancers and hostesses, and were then forced into prostitution to pay off debts to their «agents» and "protectors». Discussion of prostitutes as migrants is a sensitive issue in which it is all too easy to slip into a discourse of unbridled victimisation. Campani (1999) points out both the appallingly tragic circumstances of trafficked women from Albania and Nigeria, and other cases where migrant prostitutes, by operating independently, are able to maintain and reassert some control over their lives and their migration projects.

If «the maid» and «the prostitute» are the two most typical occupations for immigrant women in Southern Europe (Campani, 1999), this should not be allowed to obscure a wide range of other jobs in which immigrant women participate: as workers in the tourist industry (especially as cleaners, chambermaids, kitchen staff), as nurses and auxiliaries in hospitals and other institutions of care, and as helpers in retailing, hairdressing, etc. Whilst on the one hand this represents a fairly diverse range of jobs, all have one thing in common: they can all be regarded as traditional female jobs and an extension of the stereotyped role of women in Southern Europe and Catholic societies as carers/helpers/cleaners etc. Hence it is no surprise that the main origin countries for female labour migrants (see Table 3 for the Italian case) are Catholic countries where this model of gender relations and female comportment is strongly embedded.

\section{Conclusions}

This paper has shown that, at a macro-level, recent immigration into Southern Europe is driven, firstly, by powerful economic forces linked to uneven international development; secondly by changes in the global economy and labour market which have affected demands for female labour; and thirdly by the evolving internal structure of the South European economy which can be regarded as a specific type of European development. In the overall map of 
European economic and demographic restructuring several key transformations such as the expansion of the service sector, the casualisation and informalisation of work, birth rate decline and ageing, have proceeded further and faster than in other parts of Europe (Blotevogel and King, 1996). Immigration flows have been an important accompaniment of these transformations.

At a more micro-level, we have shown that the Southern European economy is divided up into a number of subsectors defined by job type, location, pay and working conditions. Partly this corresponds to the division (perhaps continuum would be a better word) between the formal and the informal economy, but there is in addition a more complex segmentation into a large number of labour market niches which, as they have evolved and have become more specialised, have taken on distinct ethnic and gender characteristics. In particular, the strong expansion of the service sector, especially in the area of personal and domestic services, has favoured the immigration of female over male workers.

In this new «migration landscape» women migrate increasingly on their own, and on their own initiative. They pioneer migration chains in which men play a subordinate role, even economically, since the Southern European labour market generally offers them less opportunity and security than their sisters (Chell, 1997). Nevertheless, when women enter Southern Europe they find themselves in a sharply gendered labour market and in a still-patriarchal society which forces them to take on «female» jobs as maids, nurses, carers, entertainers, prostitutes etc. But immigrant women do not resign themselves passively to this situation and have reacted to the various forms of discrimination and abuse of which they are victims, largely thanks to the solidarity of their own ethnically-based migration networks. Across the Southern European region, migrant women's associations are raising awareness at the local and national level about the problems they have to face - as Orsini-Jones and Gattullo (1995) have documented in Bologna.

The survey we have offered above is only part of the story. To fully understand the meaning of migration, both at the level of the individual and in terms of migration's capacity to transform the economies and societies of the countries of origin, the analysis has to start, and to end, in the setting of the sending society. What are the effects of the hard and often degrading work performed by migrant women in Southern Europe on the communities they left, send remittances back to, and hope one day to return to? How is the economic and social behaviour of migrant women in Southern Europe conditioned by their links to home and by the "control» exercised over them by their families and other migrant agents? For these women of the Third (and Second) Worlds, does emigration to Southern Europe represent a migration of progress from «rural archaism» to emancipation? (Tienda and Booth, 1991). From the Southern European end these are questions that are rarely asked. But a proper exploration of these issues, which means research in Cape Verde, the Philippines or wherever, is necessary for a full understanding of the migratory space of women's lives. There are signs that such research is beginning to 
be done, with important studies already completed on female Moroccan migrants in Italy and Morocco (De Bernart et al., 1995) and on Filipino, Gambian and Moroccan migrants in Catalonia and in their home countries (Ribas Mateos, 1997).

\section{References}

ANDALL, J. (1998). «Catholic and state constructions of domestic workers: the case of Cape Verdean women in Rome in the 1970s». In Koser, K.; LuTZ, H. (eds.). The New Migration in Europe: Social Constructions and Social Realities. London: Macmillan, p. 124-142.

BAGANHA, M.I. (1998). «Immigrant involvement in the informal economy: the Portuguese case». Journal of Ethnic and Migration Studies, 24(2): 367-386.

BALDWIN-EDWARDS, M. (1997). "The emerging European immigration regime: some reflections on implications for Southern Europe». Journal of Common Market Studies, 35(4): 497-519.

BloteVogel, H.H.; King, R. (1996). «European economic restructuring: demographic responses and feedbacks». European Urban and Regional Studies, 3(2): 133-159.

Brettell, C.B. (1982). We Have Already Cried Many Tears: The Stories of Three Portuguese Migrant Women. Cambridge: Schenkman.

CAMPANI, G. (1999). "Immigrant women in Southern Europe: gender, social exclusion and prostitution in Italy». In KING, R.; LAZARIDIS, G.; TSARDANIDIS, C. (eds.). Eldorado or Fortress? Migration in Southern Europe. London: Macmillan, p. 145-169.

CARITAS DI ROMA (1997). Immigrazione Dossier Statistico '97. Rome: Anterem.

CAstles, S.; Miller, M.J. (1993). The Age of Migration. London: Macmillan.

Chell, V. (1997). "Gender-selective migration: Somalian and Filipino women in Rome». In KING, R.; BLACK, R. (eds.). Southern Europe and the New Immigrations. Brighton: Sussex Academic Press, p. 75-92.

CORNELISEN, A. (1976). Women of the Shadows. London: Macmillan.

De Benart, M.; Di Pietrogiacomo, L.; Michelini, L. (1995). Migrazioni femminili, famiglia e reti sociali tra il Marocco e l'Italia. Turin: L'Harmattan Italia.

De FilipPo, E. (1994). «Le lavoratrici "giorno e notte"». In ViCARELLI, G. (ed.). Le mani invisibili. Rome: Ediesse, p. 65-72.

DOUGLASS, W.A. (1976) «Serving girls and shepherders: emigration and continuity in a Spanish Basque village». In ACEVES, J.B.; DOUGLASS, W.A. (eds.). The Changing Faces of Rural Spain. New York: Schenkman, p. 45-61.

DrouKAS, E. (1998). "Albanians in the Greek informal economy». Journal of Ethnic and Migration Studies, 24(2): 347-366.

ESCRIVÁ, A. (1997). "Control, composition and character of new migration to southwest Europe: the case of Peruvian women in Barcelona». New Community, 23(1): 43-57.

EuropeAn COMMISSION (1996). Employment in Europe. Luxembourg: DirectorateGeneral for Employment and Social Affairs.

HugO, G. (1998). "Globalisation and international migration in Asia». Studi Emigrazione, 35(129): 2-48.

IOSIFIDES, T.; KING, R. (1996). «Recent immigration to Southern Europe: the socioeconomic and labour market contexts». Journal of Area Studies, 9: 70-94. 
KING, R. (1997). «Population growth: an avoidable crisis?». In KING, R.; ProudFOOT, L.; SMITH, B. (eds.). The Mediterranean: Environment and Society. London: Arnold, 164-180.

- (1998). «The Mediterranean: Europe's Rio Grande». In ANDERSON, M.; BorT, E. (eds.). The Frontiers of Europe. London: Pinter, p. 109-134.

KING, R.; FIELDING, A.J.; BLACK, R. (1997). «The international migration turnaround in Southern Europe». In KING, R.; BLACK, R. (eds.). Southern Europe and the New Immigrations. Brighton: Sussex Academic Press, p. 1-25.

KING, R.; KonjHodzic, I. (1995). Labour, Employment and Migration in Southern Europe. Brighton: University of Sussex Research Papers in Geography 19.

KING, R.; RYBACZUK, K. (1993). «Southern Europe and the international division of labour: from mass emigration to mass immigration». In KING, R. (ed.). The New Geography of European Migrations. London: Belhaven, p. 175-206.

LAZARIDIS, G.; ROMANISZYN, K. (1998). «Albanian and Polish undocumented workers in Greece: a comparative analysis». Journal of European Social Policy 8(1): $1-22$.

Mingione, E. (1995). «Labour market segmentation and informal work in Southern Europe». European Urban and Regional Studies, 2(2): 121-143.

MingIONE, E.; QUASSOLI, F. (1999). «The participation of immigrants in the underground economy in Italy». In KING, R.; LAZARIDIS, G.; TSARDINIDIS, C. (eds.). Eldorado or Fortress? Southern Europe and Immigration. London: Macmillan, p. 27-56.

MONTANARI, A.; CORTESE, A. (1993). «South to North migration in a Mediterranean perspective». In KING, R. (ed.). Mass Migrations in Europe: the Legacy and the Future. London: Belhaven, p. 212-233.

MOROKVASIC, M. (1984). «Birds of passage are also women». International Migration Review, 18(4): 886-907.

OECD (1991). Labour Force Statistics 1970-1990. Paris: OECD.

Orsini-Jones, M.; GATtUllo, F. (1995). «Visibility at a price? Black women in Red Bologna». Tuttitalia, 14: 24-38.

PANAYOTAKOPOULOU, E. (1981). «Specific problems of migrant women returning to the country of origin, particularly as regards employment and social services». International Migration, 19(1-2): 219-224.

PhizaCKLEA, A. (ed.) (1983). One Way Ticket: Migration and Female Labour. London: Routledge and Kegan Paul.

Piore, M.J. (1979). Birds of Passage: Migrant Labour and Industrial Societies. Cambridge: Cambridge University Press.

Pugliese, E. (1993). «Restructuring of the labour market and the role of Third World migrations in Europe». Society and Space, 11(4): 513-522.

REYNERI, E. (1998). "The role of the underground economy in irregular migration to Italy: cause or effect?». Journal of Ethnic and Migration Studies, 24(2): 313-331.

RibAS MATEOS, N. (1997). La heterogeneidad de la integración social. Una aplicación a la inmigración extracomunitaria (filipina, gambiana y marroqui) en Cataluña (1985-1996). Bellaterra: Publicacions de la Universitat Autònoma de Barcelona (tesi doctoral).

ROMANISZYN, K. (1996). «The invisible community: undocumented Polish workers in Athens». New Community, 22(2): 321-333.

SChWARTZ Seller, M. (ed.) (1981). Immigrant Women. Philadelphia: Temple University Press. 
SimON, G. (1987). «Migration in Southern Europe: an overview». In The Future of Migration. Paris: OECD, p. 259-291.

Simon, R.J.; BretTell, C.B. (eds.) (1986). International Migration: the Female Experience. Totowa NJ: Rowman and Allanheld.

SolÉ, C.; Ribas, N.; BerGalli, V.; PARella, S. (1998). «Irregular employment amongst migrants in Spanish cities». Journal of Ethnic and Migration Studies, 24(2): 333-346.

TIENDA, M.; BOOTH, K. (1991). «Gender, migration and social change». International Sociology, 6(1): 51-72.

WERTH, M.; KÖRNER, H. (1991). «Immigration of citziens from third countries into the southern member states of the EEC». Social Europe, Supplement 1/91: 1-134.

WilliamS, C.; WinderbanK, J. (1995). «Black market work in the European Community: peripheral work for peripheral localities?». International Journal of Urban and Regional Research, 19(1): 23-39. 